\title{
Fatty Acid Extraction of Skeletonema costatum by Using Avocado Oil as Solvent and Its Application as an Anti-Aging Cream
}

\author{
TRI WIDAYATI PUTRI ${ }^{1}$, INDAH RAYA ${ }^{2 *}$, HASNAH NATSIR ${ }^{2}$ and ERNA MAYASARI ${ }^{2}$ \\ ${ }^{1}$ Magister Program Student, Chemistry Departement of Hasanuddin University, Indonesia. \\ ${ }^{2}$ Department of Chemistry Hasanuddin University, Makassar, Sulawesi Selatan, Indonesia. \\ *Corresponding author E-mail: indahraya05@gmail.com
}

http://dx.doi.org/10.13005/ojc/330618

(Received: August 01, 2017; Accepted: September 10, 2017)

\begin{abstract}
The aim of this study was to analyze the fatty acid content of Skeletonema costatum crude extract by using avocado oil as the solvent and determining its effectiveness as an anti-aging cream. Sonication was used as a method for fatty acids extraction of Skeletonema costatum. Lipid content of Skeletonema costatum was analyzed by GC-MS and FTIR, while skin condition was measured by skin analyzer. The test of cream effectiveness was carried out towards 15 panelists aged 20-60. The highest fatty acid content in lipid of Skeletonema costatum crude extract reached $45.37 \%$ with a ratio of concentration 'of $1: 25 \mathrm{w} / \mathrm{v}$ than other result $(1: 10 \mathrm{w} / \mathrm{v}, 1: 20 \mathrm{w} / \mathrm{v}, 1: 30 \mathrm{w} / \mathrm{v}, 1: 35$ $\mathrm{w} / \mathrm{v}$ and $1: 40 \mathrm{w} / \mathrm{v})$. The fatty acid of Skeletonema costatum consists of palmitic acid, palmitoleic acid, linoleic acid, oleic acid and stearic acid. The results of this study showed that fatty acids can increase the skin moisture and improve the structure of the panelist's skin. This paper provides for the first time using avocado oil as a solvent to extract fatty acids of skeletonema costatum as anti aging-cream.
\end{abstract}

Keywords: Anti-aging cream, Fatty Acid, Skeletonema costatum, Avocado oil.

\section{INTRODUCTION}

The Creams that promising beauty to consumers such as anti-aging is a lot of outstanding today. Skin aging is a human change caused by physical, psychological and social factors. Antiaging reduces wrinkles or lines of expression on the face, pigmentation changes and others ${ }^{1}$. Most of the women are interested to try any kind of antiaging products. Unfortunately, the most widely marketed of anti-aging products recently is illegal anti-aging cream which does not meet the standards of good cosmetic production and contains harmful chemicals such as mercury, arsenic, lead, cadmium, and hydroquinone ${ }^{2}$.

The fatty acid is one of the cosmetic ingredients ${ }^{3}$ because it can increase the production of antioxidants ${ }^{4},{ }^{5}$ and make the skin seems smooth and soft. Antioxidants can prevent the free radicals that are the main cause of skin aging due to the exposure of UV light? 
One of Indonesia's natural potentials is microalgae or phytoplankton ${ }^{8}$. Phytoplankton contained high fatty acid ${ }^{9}$. Moreover, the fatty acid percentage in Skeletonema costatum was $31 \%{ }^{10}$.

Fatty acid extract of Skeletonema costatum by using $n$-hexane as solvent yielded $31.15 \%$ while the extraction by using chloroform yielded $41.46 \%{ }^{11}$. Nevertheless, these chemical solvents are toxic. Hence, an alternative solvent is needed for extraction of fatty acid.

Avocado oil was used as an ingredient in the cosmetics industry because it is easy to absorb and contains unsaturated fatty acids which have a positive impact on the skin ${ }^{12}$

No previous study of fatty acid extraction by using avocado oil as an alternative solvent has been reported. This study investigated the fatty acid extraction of Skeletonema costatum by using avocado oil as a solvent. This research used sonication methods which more efficient and faster than conventional methods. Sonication extraction method utilizing ultrasonic waves, $42 \mathrm{kHz}$ to accelerate the contact time between the sample and the solvent although at room temperature ${ }^{13}$.

\section{MATERIAL AND METHODS}

Main materials used in this study were spotted Skeletonema costatum powder (Production of Laboratorium Pakan Hidup Laboratory, Balai Besar Perikanan Budidaya Air Payau Jepara), avocado oil (Production Healthy Organic Store) methanol pa, stearic acid $\left(\mathrm{CH}_{3}\left(\mathrm{CH}_{2}\right)_{16} \mathrm{COOH}\right)$, triethanolamine $\left.\left(\mathrm{HOC}_{2} \mathrm{H}_{4}\right)_{3} \mathrm{~N}\right)$ is used as emulsifier because TEA can neutralize fatty acids, regulate $\mathrm{pH}$, and can dissolve oils and materials that are not soluble in water, nipagin and nipasol are used in cream preparations as additives that serve as preservatives, propylene glycol is used as a humectant in cream formulas, DPPH, vitamin $\mathrm{C}$ pa, aquades are used to provide a sense of coldness to the skin as well as a skin moisturizer, aqubides, filter paper, label paper, aluminum foil and tissue roll.

The equipment that was used in this study were common glass equipment in the laboratory, Centrifuge, digital scales, mortar and pestle, plastic pot, Erlenmeyer, pipette, Brookfield viscometer used to measure viscosity, $\mathrm{pH}$ meter used to measure $\mathrm{pH}$ of cream, pycnometer used to measure density, Ultrasonic Cleaner Krisbow 42 kHz, spectrophotometer UV-Vis US-110PC, Skin analyzer Luvance, and analysis of fatty acid composition using instruments FTIR (Fourier Transform Infra Red) Prestige-21 Shimadzu, and GC-MS QP2010S SHIMADZU.

\section{Lipid extraction of Skeletonema costatum}

As much as $0.1 \mathrm{~g}$ of dry biomass of Skeletonema costatum put in Erlenmeyer 50 $\mathrm{mL}$, then added avocado oil in the ratio of $1: 10$ $\mathrm{w} / \mathrm{v}, 1: 20 \mathrm{w} / \mathrm{v}, 1: 25 \mathrm{w} / \mathrm{v}, 1: 30 \mathrm{w} / \mathrm{v}, 1: 35 \mathrm{w} / \mathrm{v}$, and $1: 40 \mathrm{w} / \mathrm{V}$ then extracted by means of ultrasonic (sonicator) with $42 \mathrm{kHz}$ at temperature range of $50-55^{\circ} \mathrm{C}$ for $6 \mathrm{~h}$, then centrifuged to separate the extract biomass with avocado oil. The lipid was then analyzed using FTIR (Fourier Transform Infra Red) Prestige-21 Shimadzu, and GCMS QP2010S SHIMADZU to determine its fatty acid composition.

\section{Production of Skeletonema costatum cream}

Skeletonema costatum cream is M/A type or called vanishing cream semi-solid. Vanishing cream is emulsion, contains approximately $60 \%$ water and used for external skin ${ }^{14},{ }^{15}$

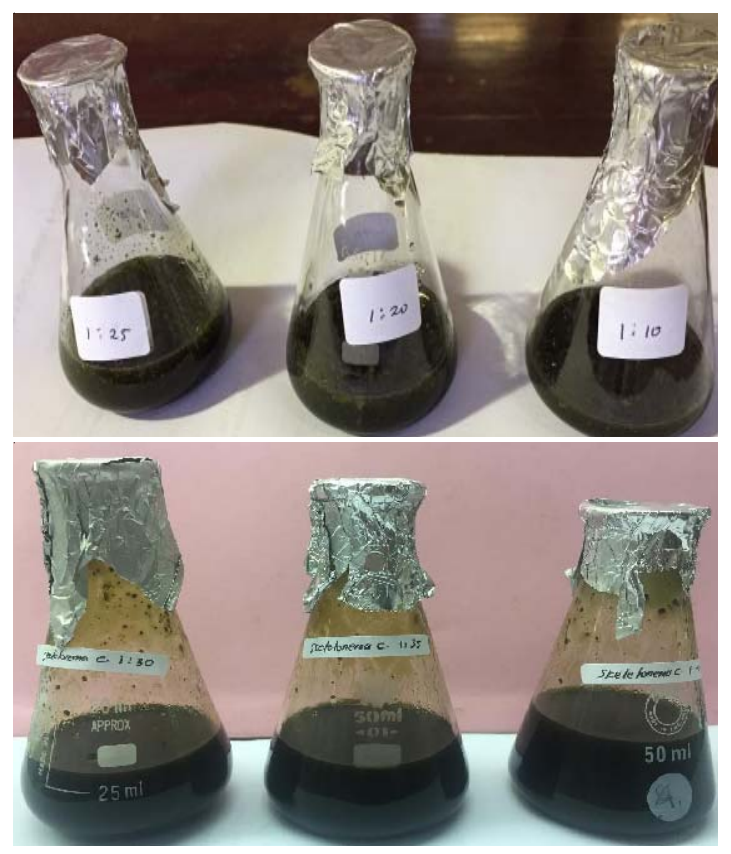

Fig.1. Skeletonema costatum crude extract 
Production of Skeletonema costatum cream and control cream composed of two phase. The first phase is oil phase consists of the highest lipid of Skeletonema costatum crude extract, stearic acid, and triethanolamine (TEA). The second phase is aqueous phase consists of aquadest, nipagin, nipasol, propylene glycol.

For Oil phase, dissolve Skeletonema costatum crude extract and stearic acid in hot motrar and added TEA. For Aqueous phase, dissolve nipagin and nipasol with propylene glycol and added aquades. A pour aqueous phase into the oil phase while stirred in a hot mortar thus forming a cream.

\begin{tabular}{lcc}
\multicolumn{3}{c}{ Tabel.1: formulation of Skeletonema costatum } \\
cream
\end{tabular}
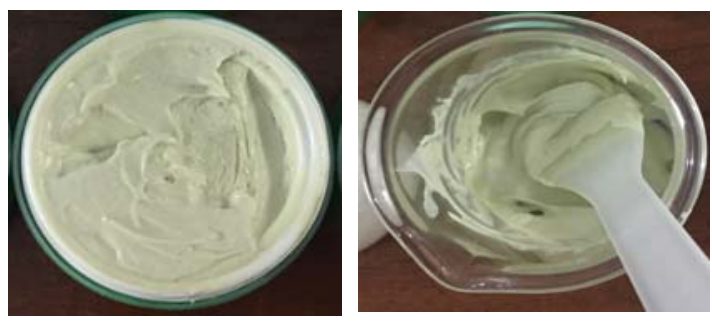

Fig. 2. Skeletonema costatum cream

The Skeletonema costatum cream then tested according to SNI 16-4399-1996 standard that is organoleptic test, $\mathrm{pH}$, density, viscosity and microbial contamination. The test of cream effectiveness was performed randomly to 15 panelists aged 20-60, and one panelist as a control. Facial skin texture tests used skin-analyzer at before and after of cream usage. Avocado oil cream (not contain Skeletonema costatum crude extract) was used as a cream control.
The $\mathrm{pH}$ test was performed by taking $1 \mathrm{~g}$ of cream diluted with aquadest (1 g: $10 \mathrm{~mL})$. The $\mathrm{pH}$ meter electrode section is inserted into the diluted sample and the number seen on the screen is the $\mathrm{pH}$ value.

Viscosity was measured using the Brookfield Viscometer. The sample is inserted into the film tube, then stand for $30 \mathrm{~min}$. at $25^{\circ} \mathrm{C}$. Spindle used is spindle number 7 with a rotational speed of $50 \mathrm{rpm}$ for 15 minutes. The viscosity value is listed on the screen. And density is measured using a pycnometer that has a temperature.

Samples were diluted with sterile diluents up to $10^{-6}$ then homogenized. One $\mathrm{ml}$ of each sample dilution in the pipette into a sterile petri dish in Duplo is then poured 12-15 mL of Plate Count Agar (PCA) liquid medium. Petri dishes are shaken slowly until the samples are well blended. The mixture is allowed to solidify, then inserted into an incubator $\left(35 \pm 1^{\circ} \mathrm{C}\right)$ with an inverted position for 24 hours. The number of microbial colonies in one gram or one $\mathrm{mL}$ of the sample is calculated by diverting the average number of colonies on the cup by the dilution factor used.

\section{Measurement of antioxidant activity of Skeletonema costatum cream}

As much as $25 \mathrm{mg}$ of Skeletonema costatum cream dissolved in $25 \mathrm{~mL}$ (1000 ppm) methanol pro analysis. Series standards were prepared in various concentrations of $20,40,80$, 160 and $320 \mathrm{ppm}$. The mixtures were put in volumetric flasks $0.01 ; 0.02 ; 0.03 ; 0.04$ and $0.05 \mathrm{~mL}$ and added $1 \mathrm{~mL}$ of DPPH solution $0.4 \mathrm{mM}$. Methanol pro analysis was added up to $5 \mathrm{~mL}$, shaken and allowed to stand for $30 \mathrm{~min}$ at the room temperature. Afterwards, the absorbance of each solution was determined at $517 \mathrm{~nm}$ by using spectrophotometer UV-Vis US-110PC. Ascorbic acid was used as standard ${ }^{16}$. Antioxidant activity expressed by percent immersion DPPH.

\section{RESULT AND DISCUSSION}

Extraction lipid of Skeletonema costatum by using avocado as solvent ( $\mathrm{g}$ microalgae: $\mathrm{mL}$ avocado oil) is 1:10 w/v, 1:20 w/v, 1:25 w/v, 1:30 w/v, $1: 35 \mathrm{w} / \mathrm{V}, 1: 40 \mathrm{w} / \mathrm{v}$ obtained the highest lipid of Skeletonema costatum crude extract is $45,37 \%$ with a ratio of $1: 25 \mathrm{w} / \mathrm{v}$. 
Figure.3 shows a chromatogram of avocado oil and lipid of Skeletonema costatum crude extract with ratio of 1:25 w/v. The avocado oil chromatogram exhibited the presence of 6 peaks with the highest abundance also shown at the 6th peak with a retention time of 39.550 . The chromatogram of Lipid of Skeletonema costatum crude extract indicated the presence of 7 peaks with the highest peak at shown at the 6th peak with a retention time of 39.560 . Based on the WILLEY229.LIB database the highest peak refers to a 9-octadecanoic acid compound known as oleic acid. This compound has MR at $\mathrm{m} / \mathrm{z} 296$. Oleic acid content of avocado oil is $55,11 \%$ and lipid of Skeletonema costatum crude extract is $56,82 \%$.

Fatty acid extract of Skeletonema costatum obtained by Pratiwi et all, 2009 by using n-hexane as solvent yielded $31.15 \%$ while the extraction by using chloroform yielded $41.46 \%$. In this study using avocado oil in the content of fatty acid extract of Skeletonema costatum as much as $45.37 \%$. From $45.37 \%$ fatty acid extract of Skeletonema costatum, oleic acid as much as $56.82 \%$ and other acid levels as shown in table 3 .

Table.2: Result Isolation of Lipid of Skeletonema costatum

\begin{tabular}{lcccc}
\hline SAMPLE & & EXTRACT & \\
$\begin{array}{c}\text { Skeletonema } \\
\text { Costatum }(\mathrm{g})\end{array}$ & $\begin{array}{c}\text { Avocado Oil } \\
(\mathrm{ml})\end{array}$ & $\begin{array}{c}\text { Dry residue } \\
\text { sample }(\mathrm{g})\end{array}$ & $\begin{array}{c}\text { Extracted } \\
\text { Sample }(\mathrm{g})\end{array}$ & $\begin{array}{c}\text { Lipid Sample } \\
(\% \mathrm{w} / \mathrm{w})\end{array}$ \\
\hline 1,05 & 10 & 0,88 & 0,17 & 16,19 \\
1,05 & 20 & 0,68 & 0,37 & 35,24 \\
1,08 & 25 & 0,59 & 0,49 & 45,37 \\
1,03 & 30 & 0,89 & 0,14 & 13,59 \\
1,02 & 35 & 0,88 & 0,14 & 13,72 \\
1,05 & 40 & 0,95 & 0,1 & 9,52 \\
\hline
\end{tabular}

Gas Chromatography-Mass Spectrometry (GC-MS)
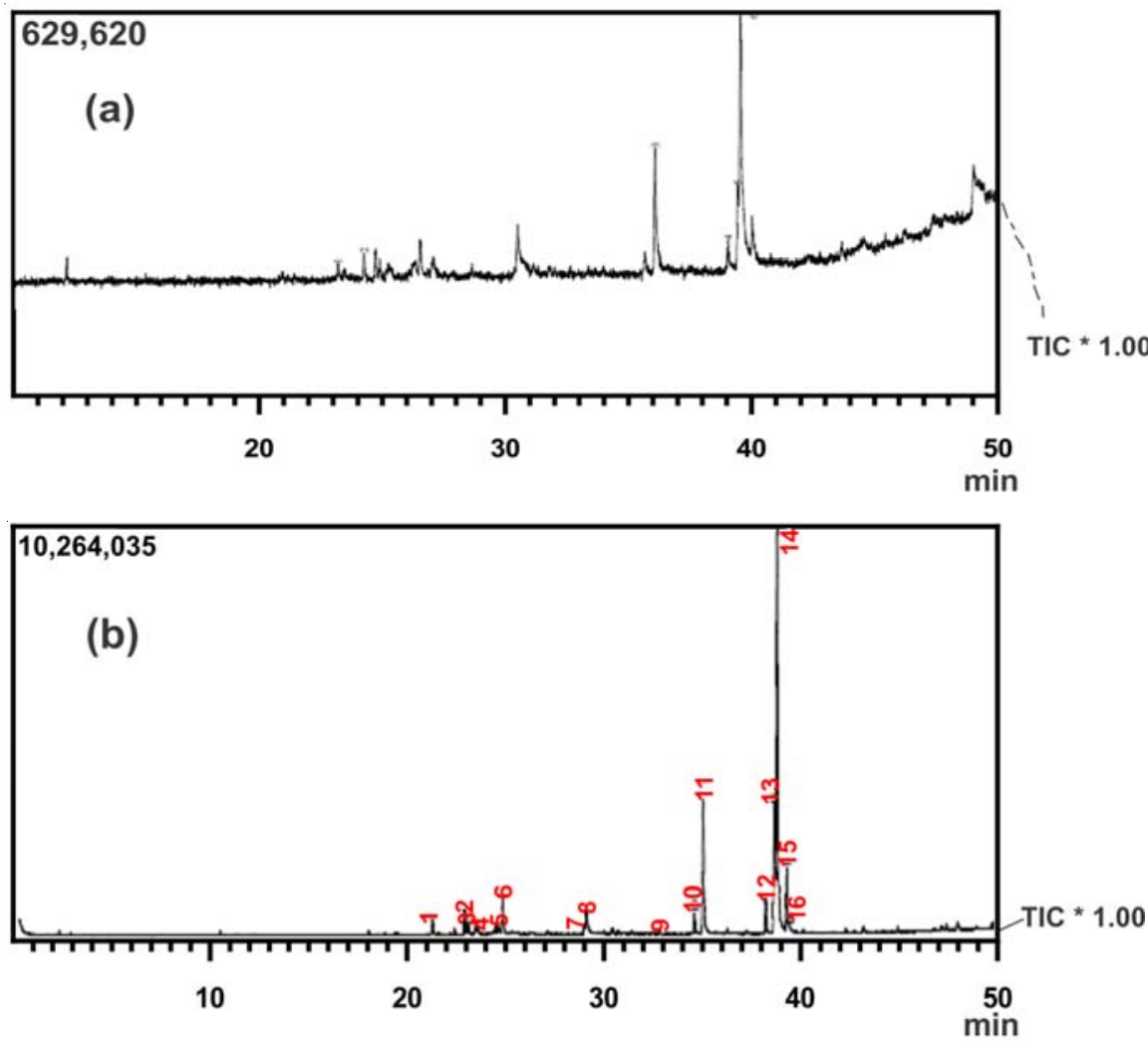

Fig.3. Avocado Oil (a) lipid of Skeletonema costatum crude extract (b) 
Table.3: Composition of avocado oil and lipid of Skeletonema costatum extract

\begin{tabular}{lcc}
\hline Fatty acid & $\begin{array}{c}\text { Avocado } \\
\text { oil (\%) }\end{array}$ & $\begin{array}{c}\text { Lipid of Skeletonema } \\
\text { costatum extract (\%) }\end{array}$ \\
\hline Palmitit acid & 23,25 & 20,30 \\
Linoleic Acid & 13,12 & 13,99 \\
Oleic Acid & 55,11 & 56,82 \\
Stearate Acid & 3,43 & 2,10 \\
Palmitoleic Acid & - & 4,26 \\
\hline
\end{tabular}

The increation and reduction of fatty acid content from lipid of Skeletonema costatum crude extract, caused by the result extract from lipid of Skeletonema costatum in the form of triglycerides in which triglycerides are composed of 3 fatty acids and glycerol. Sonication process can release fatty acid bonds in triglycerides, so that there is increased or decreased percentage of fatty acid content.

Figure. 4 describes the spectrum of fatty acids of avocado oil and lipid of Skeletonema costatum crude extract. The spectrum proved the presence of fatty acid compounds. The major bands of functional groups were listed below in table 4 .

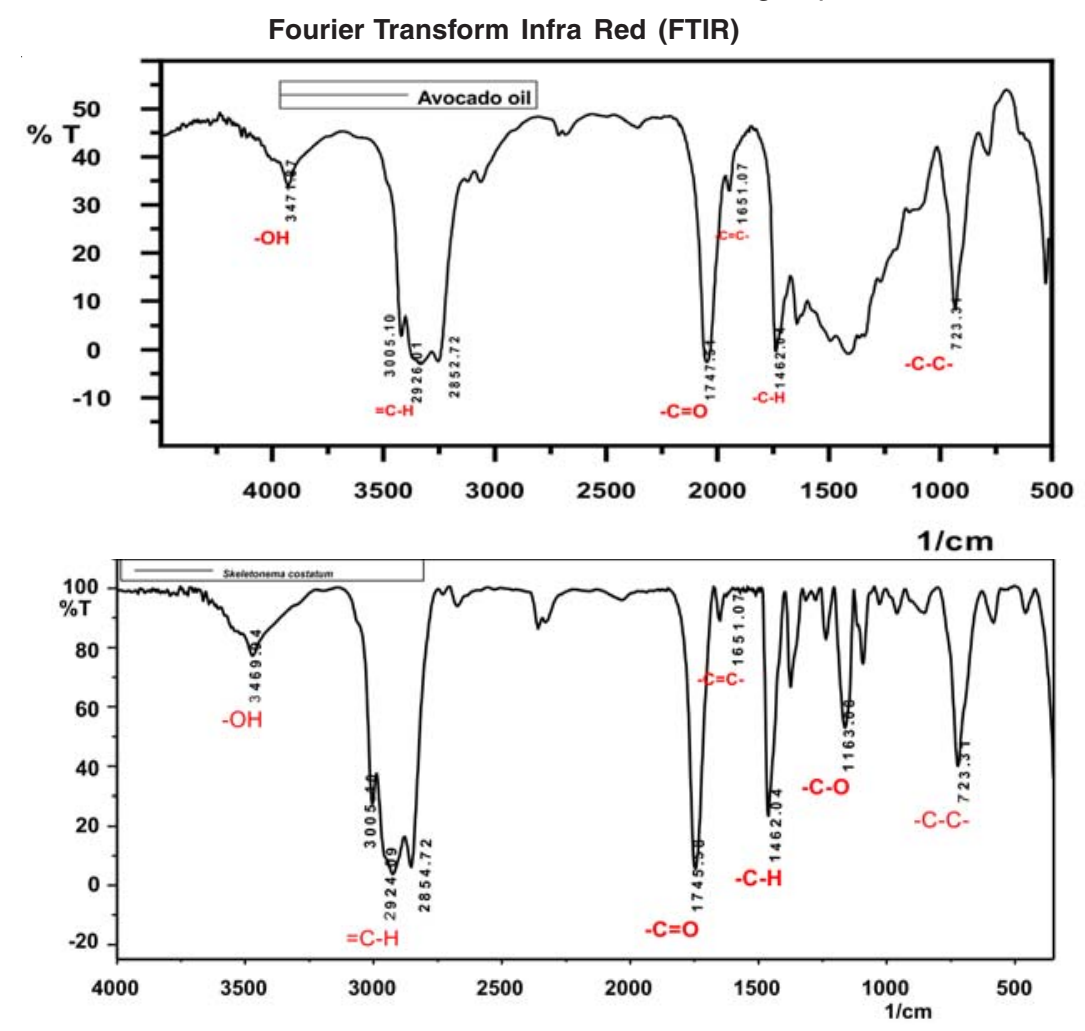

Fig.4. Spectrum of avocado oil and lipid of Skeletonema costatum crude extract

Table.4: FTIR Spectrum Tabulation

\begin{tabular}{cccc}
\hline Number & $\begin{array}{c}\text { Avocado Oil } \\
\text { Wave Numbers }\left(\mathrm{cm}^{-1}\right)\end{array}$ & $\begin{array}{c}\text { Wave Numbers Lipid } \\
\text { of Skeletonema costatum } \\
\text { extract( }\left(\mathrm{cm}^{-1}\right)\end{array}$ & Information \\
\hline 1 & 3471,87 & 3469,94 & $-\mathrm{OH}$ \\
2 & $2852,722926,013005,10$ & $2852,722924,093005,10$ & $=\mathrm{C}-\mathrm{H}$ strecthing \\
3 & 1747,51 & 1745,58 & $-\mathrm{C}=\mathrm{O}$ \\
4 & 1651,07 & 1651,07 & $-\mathrm{C}=\mathrm{C}-$ Strecthing \\
5 & 1462,04 & 1462,04 & $-\mathrm{C}-\mathrm{H}$ bending \\
6 & 723,31 & 723,31 & $-\mathrm{C}-\mathrm{C}-$ rocking \\
7 & - & 1163,08 & C-O \\
\hline
\end{tabular}


Table.5: Antioxidant Value of Skeletonema costatum Cream, and Avocado Oil cream

\begin{tabular}{cc}
\hline Cream Sample & $\mathrm{IC}_{50}$ Value $(\mu \mathrm{g} / \mathrm{mL})$ \\
\hline A & 617,938 \\
B & $1.103,711$ \\
Ascorbate acid & 2,896 \\
\hline
\end{tabular}

Antioxidant activity of Skeletonema costatum cream

Antioxidants are compounds that can inhibit oxidation reactions, by binding to free radicals and highly reactive molecules so that cell damage will be inhibited ${ }^{17}$. The method used in the antioxidant activity test in this cream is the DPPH method.

Principle of decrease in absorbance values is used to determine the antioxidant activity of a compound. The results of the DPPH method are generally made in the form of $\mathrm{IC}_{50}$ (Inhibitor Concentration 50), which is defined as the concentration of the sample solution which will reduce DPPH activity by $50 \%{ }^{18}$.

A compound can be called a very strong antioxidants if $\mathrm{IC}_{50}<50 \mathrm{ppm}$, strong antioxidants if $\mathrm{IC}_{50}$ value about 50-100 ppm, medium antioxidants if $I_{50}$ value about $101-150 \mathrm{ppm}$, and weak antioxidants if IC50> $150 \mathrm{ppm}^{19}$.

Sample $A$ is a Skeletonema costatum cream and sample B is a control cream (Avocado Oil cream). Antioxidant activity of cream $B$ is weaker than cream A. Nevertheless cream A has weaker
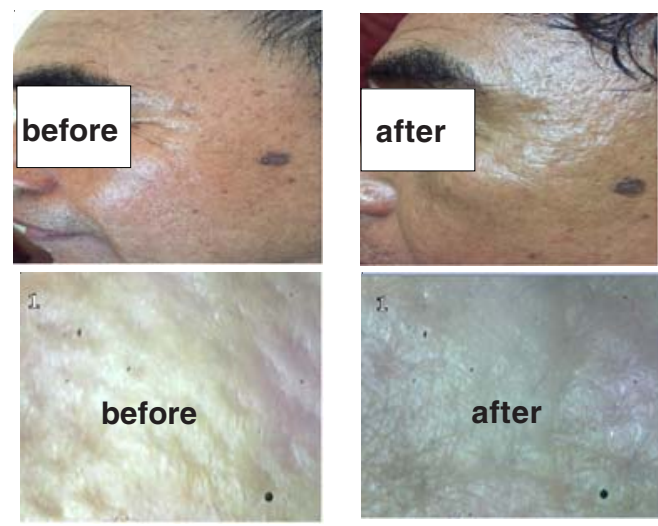

Fig.5. Panelists applicated Skeletonema costatum cream on facial skin antioxidant activity than ascorbic acid. Ascorbic acid in this case as vitamin $C$ which is the strongest antioxidant. The Cream samples containing microalgae extracts have the strongest antioxidant than do not contain microalgae extracts.

\section{Profile of Skeletonema costatum cream}

The results test of Skeletonema costatum cream was apporpriate with quality standard SNI 16-4399-1996 about the standards of good cosmetic production. Skeletonema costatum cream is green have a $\mathrm{pH}$ is 6.2 ; density is $0,978 \mathrm{~g} / \mathrm{cm}^{3}$ and viscosity is 14,666,667 Cps.. The use of Skeletonema costatum cream does not irritate the skin, it does not itch, it is not flushed and not rough or scaly after it is applied on the facial skin. Table.6: Percentage of Changes on Facial Skin
of Panelists

\begin{tabular}{lccc}
\hline Observation & $\begin{array}{c}\text { Increase } \\
(\%)\end{array}$ & $\begin{array}{c}\text { Decrease } \\
\mathbf{( \% )}\end{array}$ & $\begin{array}{c}\text { Costant } \\
\mathbf{( \% )}\end{array}$ \\
\hline Water Content & 85.7 & 14.3 & - \\
Oil Content & 85.7 & - & 14.3 \\
Cells & 78.6 & - & 21.4 \\
\hline
\end{tabular}

\begin{tabular}{lcc} 
& $\begin{array}{c}\text { water content } \\
\text { before }\end{array}$ & $\begin{array}{c}\text { water content } \\
\text { after }\end{array}$ \\
\hline age $20-30$ & 39.214 & 40.178 \\
age $31-50$ & 37.833 & 40.083 \\
\hline
\end{tabular}

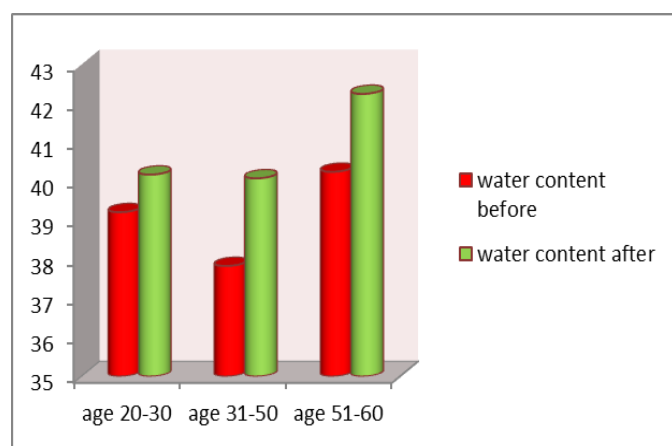

\begin{tabular}{|cl|}
\hline Score reference : & \\
$<=33 \%$ & $=$ Very dry skin \\
$34 \%-37 \%$ & $=$ Dry skin \\
$38 \%-42 \%$ & $=$ Normal skin \\
$43 \%-46 \%$ & $=$ Moisture skin \\
$>=47 \%$ & $=$ Very moisture skin \\
&
\end{tabular}



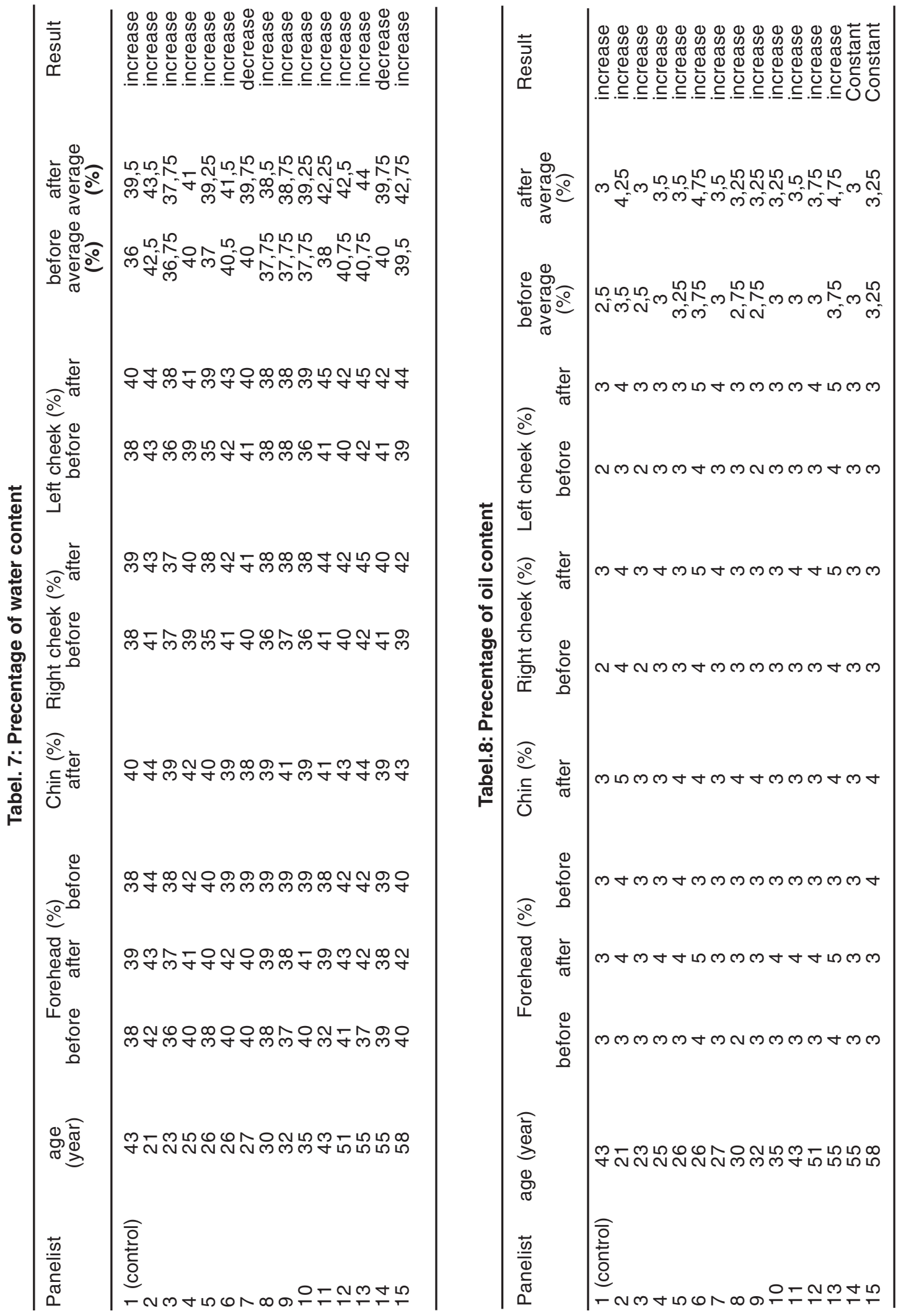


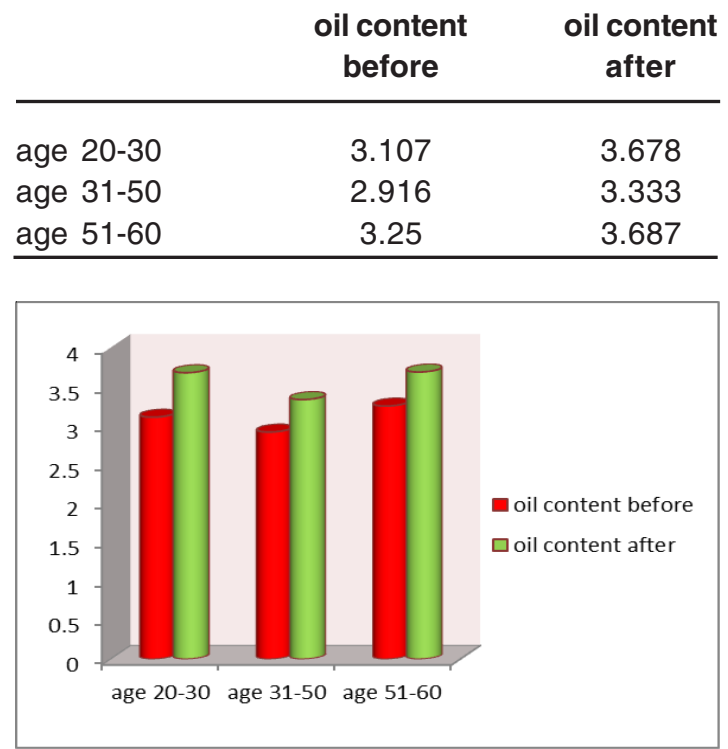

\begin{tabular}{|rl|}
\hline Score reference : & \\
1 & $=$ Very dry skin \\
2 & $=$ Dry skin \\
3 & $=$ Normal skin \\
4 & $=$ Oily skin \\
5 & $=$ Very oily skin
\end{tabular}

\begin{tabular}{lcc} 
& cell before & cell after \\
\hline age $20-30$ & 2.928 & 3.285 \\
age $31-50$ & 2.75 & 3.333 \\
age $51-60$ & 2.812 & 3.5 \\
\hline
\end{tabular}

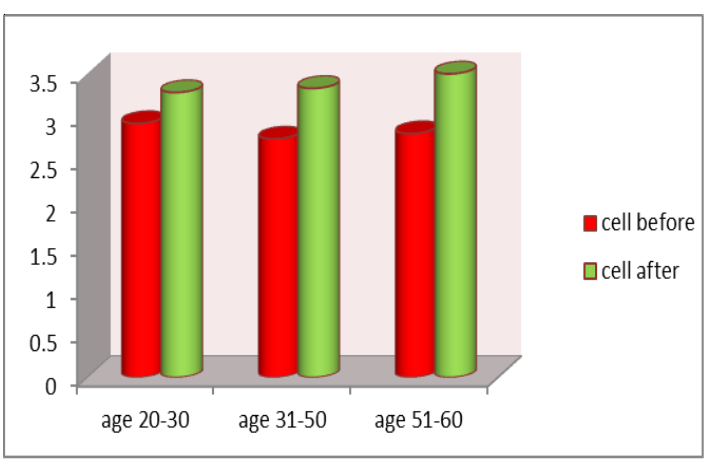

$$
\begin{array}{|rl}
\text { Score reference : } & \\
1 & =\text { Rough } \\
2 & =\text { Rougher than average } \\
3 & =\text { Average } \\
4 & =\text { Softer than average } \\
5 & =\text { Good }
\end{array}
$$

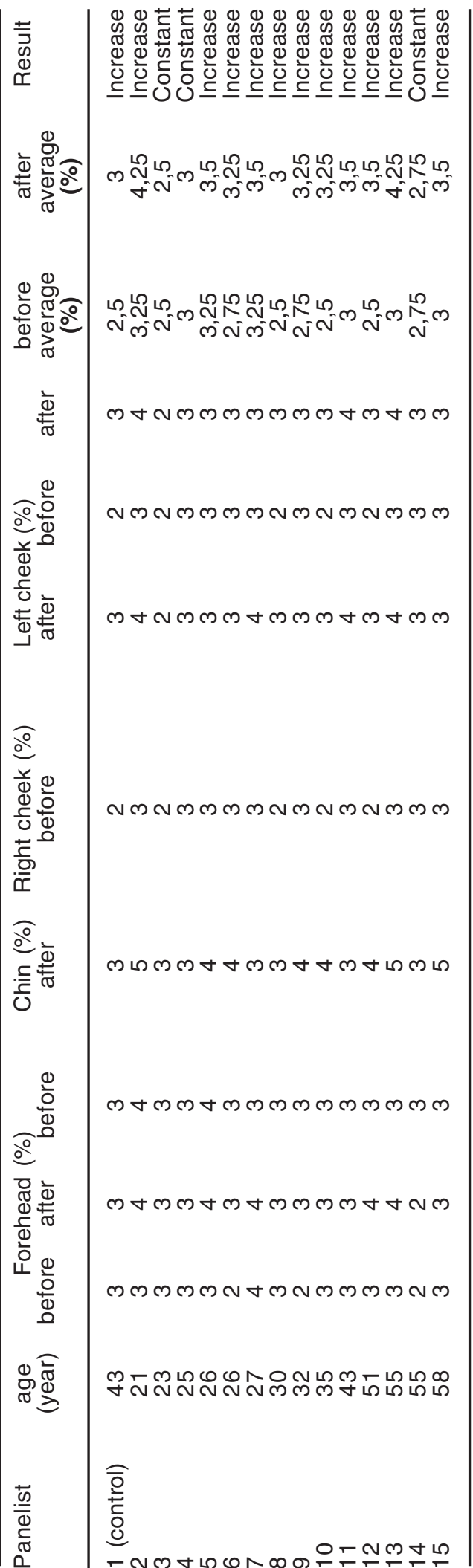


Effectiveness of Skeletonema costatum extract as anti aging cream

The application of Skeletonema costatum cream on facial skin was seen a smoother skin texture than before the use of Skeletonema costatum cream. Skeletonema costatatum cream can increase in skin moisture as measured by using skin analyzer.

The use of Skeletonema costatum cream for one month on the panelist facial skin shows the wrinkles on the face of the panelist was reduced. The result of skin analyser tests also shows improved skin texture due to an increase of water content and oil content on the panelist skin.

Two mechanisms of moisturizing cream on the skinnamely; firstly, increasing the capacity of water bound (water holding) in Stratum Corneum of hygroscopic material called humectants. These materials serve to replace the NMF (Natural Moisturizing Factor) that has been released or lost. Mechanism of humectants in skin same as both the NMF and humectants used commonly in moisturizers which derived from components of skin NMF such as lactic acid. Secondly, storing water in the Stratum Corneum layer by oily materials on the surface of the skin. Oily emollient materials help to restore impaired water barrier function in lost lipid areas ${ }^{20}$.

Skin examination by using skin-analyzer tool to measure the level of water content, oil content and panelist skin cells. Water means moist/water level of skin. Oil means oil level of skin. Cells means thickness of cuticle.
Operate Skin-Analyzer was put the two contacting dots on your skin tightly and starts to measure skin. When the measurement is complete, one beep signal apprears. The LCD display will show the score.

Table. 6 shows a change of facial skin that uses skeletonema costatum cream in the form of percentage increase, percentage decrease and percentage constant based on moisture content, oil and cells. Measurements using by skin-analyzer were performed before and after the use of the Skeletonema costatum cream.

\section{CONCLUSION}

1. fatty acid contents of Skeletonema costatum crude extract using avocado oil as solvent consist oleic acid, linoleic acid, palmitate acid, palmitoleic acid, and stearate acid

2. Skeletonema costatum cream can improve moisture and improve the structure of the panelist's skin that effective as an anti aging cream. The marked by increase of percentage water content, oil and cells.

\section{ACKNOWLEDGEMENTS}

The authors would like thankful to Anorganik Laboratory, PCA Science Building Hasanuddin University, and Organic Chemistry Laboratory Gajah Mada University for providing the research facilities.

\section{REFERENCES}

1. Sharma, B.; Sharma, A. Future Prospetcs of Nanotechnology in Development of AntiAgeing Formulations, Review Artikel, International Journal of Pharmacy and Pharmaceutical Sciences. 2012, 4, 3.

2. Badan Pengawas Obat dan Makanan. Deteksi Cemaran Logam Berat dalam Kosmetika. 2016. Lampiran Public Warning No. Hm.03.04.1.43.11.16.8233

3. Hans, L. Active Agents-the Effective Skin Care: Lipids, the Basic Elements, Articles published in Kosmetische Praxis. 2003, 6, 6-8

4. García-Inzaa, G.P.; Castroa, D. N.; Hall, A. J.;
M.C. J. Agronomy. 2016, 76, 138-147.

5. Perdones, A.; Vargas, M.; Atarés, L.; and Chiralt, A. Food Hydrocolloids. 2014, 36, 256-264.

6. Sun, R.; Gao, L.; Xiaoping Yu; Zheng, Y.; Dongdong Li; Xinguang Wang. Gene. 2016, 591, 21-26.

7. Hyun-Ah; Bao-ning, S.; Keller, W.J. and Dauglas, A.K. Journal of Agricultural and Food Chemical. 2006, 56, 6, 2077-2082.

8. Kwangdinata, R.; Raya, I.; Zakir, M. The Scientific World Journal. 2014, 5, Article ID 231361.

9. Perez-Garcia, O.; Escalante, F. M.E.; Luz, de- 
Bashan; Bashan, Y. Water Research. 2011, 45, 11-36.

10. Widianingsih, R.; Hartati, H.; Endrawati, J.; and Mamuaja. Journal of Tropical Biology and Conservation. 2013, 10, 75-82.

11. Pratiwi, A.R.; Syah, B.; Hardjito, L.; Panggabean, L.M.G.; and Suhartono, M.T. Hayati J. Biosci. 2009, 16, 4, 151-156.

12. Rahmawati, R. Khasiat Dan Cara Olah Alpukat: Untuk Kesehatan Dan Bisnis Makanan., Yogyakarta: Pustaka Baru Press, 2011.

13. Raya, I.; Anshar, A.M.; Mayasari, E.; Dwiyana, Z.; and Asdar, M. International Journal of Applied Chemistry. 2016, 12, 4, 539-548.

14. Tranggono, R.I.; and Latifah, F. Pegangan IImu Pengetahuan Kosmetik. 2007. PT Gramedia Pustaka Utama, Jakarta.

15. Ikhsanudin, A.. Jurnal IImiah Kefarmasian. 2012, 2, 2, 175-186.
16. Borra, S.K.; Gurumurthy, P.; Mahendra, J.; Jayamathi, K. M.; Cherian, C.N. and Chand R. Journal of Medicinal Plants Research. 2013, 7, 36, 2680-2690.

17. Andayani, R.; Maimunah and Lisawati, Y. Jurnal Sains dan Teknologi Farmasi, 2008, 13, $1-9$

18. Molyneux, P. J. Sci. Tech. 2004, 26, 211-219.

19. Wikanta, T.; Chasanah, E.; Amini, S.; Nursid, M.; Fajarningsih, N.D.; Januar, H.I. and Marraskuranto, E. Isolasi dan Uji Farmakologi Senyawa Bioaktif dari Biota Laut, Report of Balai Riset Pengolahan Produk and Bioteknologi Kelautan and Perikanan, Ministry of Kelautan and Perikanan. 2006. Jakarta: 9-13.

20. Leyden, J. J., 2002, Skin Moisturization, Marcel Dekker, Inc., New York, Basel, ISBN: 0-8247-0643-9. 